\title{
PHD Finger Protein 20
}

National Cancer Institute

\section{Source}

National Cancer Institute. PHD Finger Protein 20. NCI Thesaurus. Code C106060.

PHD finger protein 20 (1012 aa, 115 kDa) is encoded by the human PHF20 gene. This protein plays a role in the acetylation of histones and transcriptional regulation. 